\title{
CUKRZYCA I OTYŁOŚĆ U PACJENTÓW Z REUMATOIDALNYM ZAPALENIEM STAWÓW (RZS) JAKO CZYNNIKI POGARSZAJACQCE PRZEBIEG CHOROBY
}

\author{
DIABETES AND OBESITY IN PATIENTS WITH RHEUMATOID ARTHRITIS (RA) AS A FACTOR \\ OFDISEASE DETERIORATION
}

\author{
Magdalena Baran ${ }^{1}$, Marta Majorczyk ${ }^{1}$, Jolanta Jaworek ${ }^{2}$ \\ ${ }^{1}$ studentka studiów doktoranckich \\ Uniwersytet Jagielloński - Collegium Medicum \\ ${ }^{2}$ Zakład Fizjologii Medycznej, Instytut Fizjoterapii \\ Uniwersytet Jagielloński - Collegium Medicum
}

DOI: http://dx.doi.org/10.20883/pielpol.2016.15

\begin{abstract}
STRESZCZENIE
Reumatoidalne zapalenie stawów jest chorobą przewlekłą o podłożu autoimmunologicznym. Nierzadko reumatoidalnemu zapaleniu stawów towarzyszą inne choroby wspótistniejące mające także podłoże zapalne. Tymi schorzeniami często są jednostki chorobowe należące do szeroko rozumianego zespołu metabolicznego. Najczęściej spotykanymi schorzeniami, które jednocześnie są uważane już za choroby cywilizacyjne, są cukrzyca i otyłość. $\mathrm{U}$ chorych na cukrzycę stwierdza się stan zapalny, którego podstawą jest insulinooporność tkankowa, a także zaburzony metabolizm glukozy. Także znaczenie dla gospodarki węglowodanowej w reumatoidalnym zapaleniu stawów mają stosowane leki. Inną chorobą zapalną towarzyszącą RZS jest otyłość. Wieloletnie badania wykazały, że komórki tkanki tłuszczowej są źródłem mediatorów zapalenia. U otyłych osób, głównie kobiet, zapalenia stawów w przebiegu RZS mają cięższy przebieg. Te dwie choroby - cukrzyca i otyłość - współistniejące z reumatoidalnym zapaleniem stawów znacząco wpływają na stan chorych, na ich jakość życia i rokowania. Celem pracy było wykazanie, na podstawie przeglądu piśmiennictwa, że wspótistnienie cukrzycy i otyłości wraz z RZS wpływa na pogorszenie przebiegu tej choroby stawów.
\end{abstract}

SŁOWA KLUCZOWE: reumatoidalne zapalenie stawów, cukrzyca, otyłość, choroby metaboliczne.

\section{Reumatoidalne zapalenie stawów}

Reumatoidalne zapalenie stawów (RZS), czyli gościec przewlekle postępujący, jest chorobą o charakterze zapalanym i podłożu autoimmunologicznym. Etiologia choroby wciąż nie jest znana. Objawy RZS dotyczą zmian stawowych i pozastawowych [1]. Charakterystycznymi objawami stawowymi RZS są: symetryczny ból i obrzęki drobnych stawów rąk i stóp, rzadziej dużych stawów, a także sztywność poranna trwającą zwykle dłużej niż godzinę. Towarzyszące dolegliwości to: uczucie przewlekłego zmęczenia, gorączka, bóle

\begin{abstract}
Rheumatoid arthritis is a chronic autoimmune disease. Rheumatoid arthritis is often accompanied by other diseases, whose etiology is related to previous inflammation. These diseases often belong to the so called metabolic syndrome. The most common conditions, which are also considered to be already civilization diseases, are diabetes mellitus and obesity. Patients with diabetes tend to have inflammation, based on tissue insulin resistance and impaired glucose metabolism. Some drugs used in the treatment of rheumatoid arthritis have also impact on carbohydrate balance. Another disease associated with rheumatoid arthritis is obesity. Recent studies have shown that adipocytes are the source of many inflammatory mediators. The course of rheumatoid arthitis is much severe in the obese patients, particularly in obese woman. These two diseases coexisting of rheumatoid arthritis significantly affect the condition of patients, their quality of life and prognosis. The aim of the study was to determine, based on the review of the literature, that the coexistence of diabetes and obesity with RA affected the worsening of this disease of the joints.
\end{abstract}

KEYWORDS: rheumatoid arthritis, diabetes, obesity, metabolic diseases.

mięśni i utrata masy ciała [1, 2]. Zmiany pozastawowe towarzyszące RZS dotyczą układu sercowo-naczyniowego, układu oddechowego (powodując utrudnienie oddychania i prawidłowego dotlenienia tkanek organizmu), nerek (powodując zaburzenia gospodarki wodno-elektrolitowej i diurezy). W RZS zmiany zapalne mogą dotyczyć również skóry, narządu wzroku i centralnego układu nerwowego [3, 4].

Kobiety chorują trzy razy częściej niż mężczyźni. Szczyt zachorowania przypada na 4. i 5. dekadę życia. U 70\% chorych występują okresy remisji i za- 
ostrzeń choroby. U 15\% chorych proces chorobowy przebiega łagodnie z umiarkowaną jego aktywnością i destrukcją kilku stawów. U około 10\% chorych remisje są długotrwałe, nawet kilkuletnie. Choroba rozwija się bardzo szybko - w ciągu kilku tygodni, a u około 15\% chorych nawet w ciągu kilku dni. W ciągu 2 lat od zachorowania u chorych z RZS może dojść do znacznej destrukcji stawów prowadzącej do niepełnosprawności [5].

\section{Zaburzenia metaboliczne w reumatoidalnym zapaleniu stawów}

Reumatoidalne zapalenie stawów jest chorobą układową, dlatego nierzadko w przebiegu RZS występują objawy pozastawowe. W dobie chorób cywilizacyjnych bardzo często współistnieją u pacjentów z RZS zaburzenia metaboliczne [6].

\section{Cukrzyca w reumatoidalnym zapaleniu stawów}

Choroby układowe tkanki łącznej niosą za sobą ryzyko wystąpienia chorób układu krążenia. W procesie diagnozowania pacjenta często stwierdza się współistniejące zaburzenia gospodarki węglowodanowej lub cukrzycę typu II [7].

Częstość wystąpienia cukrzycy u chorych na RZS szacuje się na 14-18\%. Praktyka kliniczna wskazuje na wystąpienie cukrzycy typu I, typu II, a także cukrzycy typu LADA, w której występują przeciwciała przeciwko dekarboksylazie kwasu glutaminowego. Na świecie wciąż prowadzone są badania nad związkiem cukrzycy z procesem zapalnym stawów. Wyniki tych badań są rozbieżne. J.F. Simard i M.A. Mittleman [7, 8] stwierdzili 24 przypadki cukrzycy wśród 144 chorych na RZS powyżej 60. roku życia. C. Han i wsp. [9] w dużych badaniach populacyjnych, które objęły 28 tysięcy osób, określili współczynnik zachorowania na cukrzycę typu II u chorych na RZS; wynosi on 1,4. Potwierdzeniem tych badań są badania D.H. Solomona i wsp. [10], którzy potwierdzili ten współczynnik - wyniósł on 1,5 wśród 48 tysięcy chorych na RZS.

U chorych na RZS stwierdza się zaburzenia metabolizmu glukozy i insulinooporność. Poziom glukozy we krwi zależny jest nie tylko od prawidłowego funkcjonowania komórek trzustki, ale także prawidłowego wychwytu glukozy przez komórki efektorowe, zwłaszcza mięśnie szkieletowe i komórki mięśniowe [8].

Wyniki wieloletnich badań pozwoliły na ustalenie, że cukrzyca może mieć podłoże zapalne. Opublikowane badania wskazują, że osoby otyłe charakteryzuje wysoki poziom we krwi cytokin prozapalnych - czynnika martwicy nowotworów $\alpha$ (TNF- $\alpha$ ) oraz interleukiny 6 (IL-6). Istotnie podwyższone w procesie zapalnym w przebiegu cukrzycy są także białka chemotaktyczne dla monocytów MCP1, ekspresja genu dla syntazy, a także kinaz białkowych. Dowiedziono, że przewlekły proces zapalny niezależnie od ilości występującej tkanki tłuszczowej wpływa na procesy metabolizmu glukozy i obniża poziom tkankowej wrażliwości na insulinę. Do tej pory nie poznano dokładnego patomechanizmu powstawania RZS, natomiast znane są cytokiny prozapalne (m.in.: IL-15, TNF- $\alpha, \mathrm{IL}-1-\beta, \mathrm{IL}-6$, IL-8, IL-12, IL-17, IL-18), które odgrywają znaczącą rolę w przebiegu i leczeniu RZS. Te same cytokiny spełniają ważną funkcję w powstaniu cukrzycy. Fakt ten może sugerować, że RZS i cukrzyca są schorzeniami, których patomechanizm jest podobny i mają podobne właściwości prozapalne [8].

Znajomość cytokin prozapalnych wspólnych dla RZS i cukrzycy pozwala określić i zbadać wpływ leków stosowanych w RZS na procesy zapalne charakterystyczne dla zaburzeń metabolicznych. D.H. Solomon i wsp. przeprowadzili badanie, które wykazało, że na 1000 osób z aktywnym RZS roczny wskaźnik zachorowania na cukrzycę u osób stosujących inhibiory TNF- $\alpha$ wyniósł 19,7, natomiast u stosujących metotreksat był wyższy i wyniósł 23,8 . Wynika z tego, że zablokowanie prozapalnego TNF- $\alpha$ zmniejszyło u tych osób częstość występowania cukrzycy. Z kolei metotreksat zwiększa przeciwzapalne i wzmagające metabolizm glukozy w organizmie działanie adenozyny. Zaobserwowano także po kilku miesiącach stosowania metotreksatu zmniejszenie ilości przeciwciał anty-GAD powodujących cukrzyce LADA. Stosowanie glikokortykosteroidów (GKS) znacząco wpływa na gospodarkę węglowodanową, pobudzając glukoneogenezę wątrobową, nasilając syntezę glikogenu i tym samym zwiększając poziom glukozy we krwi. GKS wpływają także na zmniejszenie wytwarzania insuliny przez komórki trzustkowe. Wieloletnie badania wykazują, że długoletnie stosowanie GKS sprzyja powstaniu cukrzycy, natomiast krótki czas leczenia kortykosteroidami nie wpływa znacząco na wzrost poziomu glikemii. M. Fleischemann i wsp. [8, 11] wykazali, że stosowanie niesteroidowych leków przeciwzapalnych (NLPZ) sprzyja obniżeniu poziomu glukozy w surowicy, a także obniża CRP i poziom peptydu C. NLPZ modulują stężenie adiponektyn, co sugeruje korzystny ich wpływ na insulinowrażliwość.

Cukrzyca jako choroba współistniejąca z RZS obciąża chorego. Zmęczenie towarzyszące RZS i zmniejszenie wydolności fizycznej utrudniają choremu funkcjonowanie. Chory musi pamiętać nie tylko o codziennych ćwiczeniach, zachowaniu prawidłowej postawy w RZS, ale także o diecie i kontroli glikemii [12].

\section{Otyłość w reumatoidalnym zapaleniu stawów}

Według Światowej Organizacji Zdrowia (WHO) na świecie żyje ponad 1,5 miliarda osób z nadwagą i blisko 
ponad 500 milionów z otyłością. Otyłość jest stanem, w którym tkanka tłuszczowa przekracza 25\% masy ciała u mężczyzn i 30\% masy ciała u kobiet [16]. Przyczyną tego stanu jest hipertrofia lub/i hiperplazja adipocytów. Za powstanie otyłości odpowiedzialnych jest kilka czynników: czynniki genetyczne, środowiskowe, społeczne, kulturowe i stan hormonalny organizmu [13]. Stwierdzono, że otyłość wpływa na wystąpienie niektórych przewlekłych chorób współistniejących, najczęściej takich jak nadciśnienie tętnicze, choroby układu krążenia, zespół metaboliczny i choroby stawów. Od niedawna prowadzi się badania kliniczne nad uwalnianymi przez tkankę tłuszczową czynnikami prozapalnymi, które odpowiadają za współistnienie chorób zapalnych z otyłością. Dotyczy to również RZS [14]. W połowie lat 80. wykazano, że tkanka tłuszczowa nie jest tylko rezerwuarem dodatkowej ilości energii, ale także miejscem przemiany steroidów i bogatym źródłem adipsyny. Adipsyna jest jedną z kilku składowych dopełniacza (składowa D) odpowiedzialnych za enzymatyczną produkcję ASP (ang. acylation stimulating protein), które jest białkiem układu dopełniacza odpowiedzialnym za metabolizm glukozy i lipidów. Wyizolowanie leptyny z adipocytów wykazało, że tkanka tłuszczowa może działać jako narząd endokrynny. Adipocyty produkują różne substancje: adiponektynę i szereg cytokin prozapalnych. Z tkanki tłuszczowej wydzielane są $\mathrm{m}$.in. istotne dla procesu zapalnego w RZS IL-6, IL-1- $\beta$ i TNF- $\alpha$. Wspomniane cytokiny wyróżnia się jako jedne z najistotniejszych w procesie rozpoznawania stanu zapalnego stawów i są one celem nowych metod leczenia za pomocą inżynierii biomedycznej [14-18].

Jakość życia chorych na RZS zależna jest głównie od stopnia zaawansowania choroby i czasu jej trwania. W początkowym okresie RZS występują ból, obrzęk stawów, a także ograniczenie ich ruchomości. Towarzysząca otyłość jest czynnikiem znacznie utrudniającym proces leczenia RZS poprzez ograniczenie mobilności pacjenta. Jakość życia chorych na RZS ze współistniejącą otyłością jest znacznie gorsza niż u osób szczupłych chorych na RZS. Chorzy poza dolegliwościami związanymi z zapaleniem stawów, jak ból, niepełnosprawność ruchowa czy stany depresyjne, muszą zmagać się z nadmierną ilością tkanki tłuszczowej, co potęguje bolesność i proces destrukcji stawów. Stawy szybciej ulegają deformacji, co widoczne jest w diagnostyce radiologicznej. Zakres ruchów czynnościowych chorego otyłego z RZS jest bardzo ograniczony, a jakość życia tych chorych jest zdecydowanie niezadowalająca. Pierwszym krokiem w leczeniu takiego chorego powinna być szybka redukcja jego masy ciała. Zmniejszenie masy ciała ma działanie przeciwzapalne i immunosupresyjne, ale również poprawia się dzięki temu stan funkcjonalny chorego. Następuje zmniejszenie syntezy mediatorów zapalenia po redukcji masy ciała. Równie ważne jest wykluczenie z diety produktów wywołujących reakcje autoimmunizacyjne i alergiczne [14-18].

\section{Podsumowanie}

Wieloletnie badania prowadzone przez naukowców na całym świecie wskazują, że osoby chore na RZS częściej niż reszta populacji zapadają na choroby należące do zespołu metabolicznego. Jednymi z najczęstszych diagnozowanych schorzeń wśród chorych na RZS są cukrzyca i otyłość. U podstaw współistnienia RZS, cukrzycy i otyłości leżą stan zapalny i procesy autoimmunologiczne. Jakość życia tych chorych znacznie pogarsza się, gdy zaczynają towarzyszyć im inne dolegliwości niż charakterystyczne dla RZS. Leczenie staje się wielokierunkowe, co wymaga także od pacjentów dodatkowej pracy włożonej w samoopiekę i samopielęgnację.

\section{Piśmiennictwo}

1. Zimmermann-Górska A (red.). Reumatologia kliniczna. Tom I. Warszawa: PZWL; 2008. 340-348.

2. Klippel J, Dieppe P, Ferri F. Reumatologia. Lublin: Czelej; 2000. 143-154.

3. Baran M, Jaworek J. Wpływ leków biologicznych na jakość życia chorych na reumatoidalne zapalenie stawów. W: Jaworek J, Frańczuk B (red.). Fizjoterapia w teorii i praktyce. Kraków: Wydawnictwo UJ; 2012: 109-127.

4. Skare TL, Nakano I, Escuissiato DL et al. Pulmonary changes on high-resolution computed tomography of patients with rheumatoid arthritis and their association with clinical, demographic, serological and therapeutic variables. Rev Bras Reumatol. 2011; 51: 325-330.

5. Głuszko P, Filipowicz-Sosnowska A, Tłustochowicz W. Reumatoidalne zapalenie stawów. Reumatologia. 2012; 50, 2: 83-90.

6. Kontny E. Nowe aspekty patogenezy spondyloartropatii zapalnych. Część II - czynniki środowiskowe, zaburzenia mikrobiomu, objawy pozastawowe. Reumatologia. 2014; 52, 3: 172-180.

7. Simard JF, Mittleman MA. Prevalent rheumatoid arthritis and diabetes among NHANES III participants aged 60 and older. J Rheumatol. 2007; 34: 469-473.

8. Dąbrowski P, Majdan M. Zaburzenia gospodarki węglowodanowej u chorych na reumatoidalne zapalenie stawów i zesztywniające zapalenie stawów kręgosłupa - wpływ stosowanego leczenia. Reumatologia. 2014; 52, 2: 129-135.

9. Han C, Robinson DW, Hackett MV et al. Cardiovascular disease and risk factors in patients with rheumatoid arthritis, psoriatic arthritis, and ankylosing spondylitis. J Rheumatol. 2006; 33: 2167-2172.

10. Solomon DH, Love TJ, Canning C, Schneeweiss S. Risk of diabetes among patients with rheumatoid arthritis, psoriatic arthritis and psoriasis. Ann Rheum Dis. 2010; 69: 2114-2117.

11. Singh VP, Bali A, Singh N. Advanced glycation end products and diabetic complications. Korean J Physiol Pharmacol. $2014 ; 18 ; 1: 1-14$. 
12. Wysocka-Skurska I, Sierakowska M, Sierakowski S. Ocena jakości życia pacjentów z reumatoidalnym zapaleniem stawów w zależności od stosowanej terapii farmakologicznej. Reumatologia. 2012; 50, 1: 16-23.

13. World Health Organization. Obesity: Preventing and Managing the Global Epidemic.

14. Karlson EW, Deane K. Environmental and gene-environment interactions and risk of rheumatoid arthritis. Rheum Dis Clin North Am. 2012; 38 (2): 405-426.

15. Mazurek T. Aktywność prozapalna tkanki tłuszczowej nowe spojrzenie na etiologię miażdżycy. Kardiol Pol. 2009; 67: 1119-1124.

16. Wąsowski M, Walicka M, Marcinowska-Suchowierska M. Otyłość - definicja, epidemiologia, patogeneza. Post Nauk Med. 2013; 4: 301-306.

17. Conde J, Scotece M, López V et al. Adipokines: novel players in rheumatic diseases. Discov Med. 2013; 15: 73-83.

18. Filipowicz-Sosnowska A, Głuszko P, Rupiński R. Profil lipidów u chorych na reumatoidalne zapalenie stawów leczonych lekami modyfikującymi przebieg choroby. Reumatologia. 2014; 52 (2): 120-128.
Artykuł przyjęty do redakcji: 09.07.2015

Artykuł przyjęty do publikacji: 03.08.2015

Źródło finansowania: Praca nie jest finansowana z żadnego źródła. Konflikt interesów: Autorzy deklarują brak konfliktu interesów.

\section{Adres do korespondencji:}

Magdalena Baran

ul. Pawła Włodkowica 3/50

31-452 Kraków

tel.: 783874294

e-mail: baranmagdalenaa@gmail.com

Uniwersytet Jagielloński - Collegium Medicum 